\title{
PENGARUH MODEL PEMBELAJARAN SELF DIRECTED LEARNING DAN SMALL GROUP DISCUSSION TERHADAP NILAI MAHASISWA MATERI MEKATRONIK
}

\author{
Wiji Lestariningsih ${ }^{1}$, Ahsan Muafa ${ }^{2}$ \\ Fakultas Teknik \\ Universitas Maarif Hasyim Latif, Sidoarjo, Indonesia \\ e-mail : ${ }^{1}$ wiji_lestariningsih@dosen.umaha.ac.id, ${ }^{2}$ ahsanmuafa@dosen.umaha.ac.id \\ Diterima: 18 April 2018. Disetujui : 15 Juni 2018. Dipublikasikan : 29 Juni 2018 \\ (C)2018 -TESJ Fakultas Teknik Universitas Maarif Hasyim Latif. Ini adalah artikel dengan \\ akses terbuka di bawah lisensi CC BY 4.0 (https://creativecommons.org/licenses/by/4.0/)
}

ABSTRAK

Penelitian ini mempunyai tujuan menganalisis penilaian sikap, penilaian pengetahuan dan penilaian keterampilan pada materi Mekatronik mahasiswa meggunakan model pembelajaran self directed learning (SDL) dan mahasiswa menggunakan model small group discussion (SGD). Metode yang digunakan adalah metode kuantitatif dengan jenis quasi eksperimental design. Penelitian ini menggunakan control group discussion pretest-postest design. Dari penelitian yang sudah dilakukan memperoleh hasil penilaian bahwa mahasiswa yang diajarkan dengan model SDL nilai rata-rata pengetahuan 81,53; nilai rata-rata keterampilan sebesar 81,76. Sedangkan pada mahasiswa yang diajarkan menggunakan SGD nilai rata-rata pengetahuan 77,25; nilai rata-rata mahasiswa keterampilan sebesar 72,97.

Kata kunci: mekatronik, model pembelajaran, nilai

\section{PENDAHULUAN}

Proses kegiatan pembelajaran merupakan hal yang menunjang keberhasilan Dosen memberikan bimbingan bagi mahasiswa dalam melaksanakan konstruksi pengalamannya sebagai awal mengkontruksi ilmu dan pengetahuan yang dimilikinya. Keberhasilan suatu proses pendidikan dalam suatu perkuliahan tidak terlepas dari merencakan kegiatan dalam kelas yang sudah ditetapkan oleh suatu lembaga atau institusi yang berupa standar. Standar tersebut merupakan acuan pencapaian kompetensi oleh mahasiswa, standar yang dimaksud yaitu meliputi rencana, pelaksanaan, penilaian dan pengawasan. Telah dilakukan beberapa hal dengan upaya dalam kegiatan perkuliahan di dalam kelas agar tercapai seluruh tujuan.

Hasil pengamatan/observasi di kelas dan wawancara dengan Ketua Program Studi Teknik Mesin memperoleh temuan bahwa saat KBM di kelas maupun di laboratorium ada beberapa kekurangan dalam pembelajaran. Pengaturan pribadi mahasiwa dan kurangnya kesadaran mengakibatkan nilai kurang memuaskan. Nilai pada materi Mekatronik aspek sikap rata-rata 70, aspek pengetahuan rata-rata 59, dan keterampilan menunjukkan rata-rata 72 .

Dari uraian nilai tersebut menunjukkan nilai pada materi Mekatronik masih di bawah standar kriteria minimal program studi. Pada prodi atau jurusan tersebut masih belum memenuhi standar program studi. Pada saat observasi terdapat salah satu kompetensi yaitu mengenai mekatronik diperoleh data nilai yang tidak memenuhi standar kriteria minimal program studi khususnya aspek pengetahuan. Mahasiswa lebih tertarik dengan dengan kegiatan yang bersifat praktek daripada hanya teori di dalam kelas. Sedangkan kurikulum KKNI pada level 6 menuntut penilaian tidak hanya mencakup aspek sikap dan pengetahuan saja tetapi sekaligus aspek keterampilan mahasiswa. Pada kompetensi Mekatronik, mahasiswa diharapkan untuk lebih memahami dasar teori, memiliki daya nalar, analisis, dan berfikir tinggi, sehingga dibutuhkan suatu inovasi yang mampu memudahkan mahasiswa dan mendorong mahasiswa lebih aktif, mengatur dirinya sendiri, mengorganisasi kebutuhan belajarnya sendiri.

Penerapan pembelajaran SDL di kelas pada Program Studi Teknik Mesin yang akan diajarkan memberikan perubahan cara pembelajaran dan penilaian yang memenuhi aspek sesuai standar minimum kurikulum yang sudah dicanangkan oleh institusi.

Tahap dalam SDL meliputi perencanaan, penerapan, pengawasan, dan penilaian. Dosen merencanakan pembelajaran atau perkuliahan baik di kelas maupun laboratorium, menerapkan perkuliahan yang bersifat mandiri kepada mahasiswa yaitu mereka mencari, menemukan sendiri hal-hal yang berkaitan dengan mekatronik, 
dosen mengawasi hasil pembelajaran tersebut dengan cara menjadi fasilitator pada saat perkuliahan, menumbuhkan rasa percaya diri atas semua hal yang sudah ditemukan dan didapat dari pembelajaran yang dilakukan. Penilaian merupakan tahap terakhir dalam SDL yang menunjukkan hasil perkuliahan mekatronik yang ditunjukkan dengan besaran nilai, penilaian tersebut terdiri dari aspek sikap dan keterampilan yang ditunjukkan dengan lembar pengamatan dan aspek pengetahuan yang ditunjukkan dengan hasil tes yang dikerjakan mahasiswa yang memenuhi materi mekatronik.

Tahap SGD meliputi membuat rancangan diskusi tentang materi mekatronik, dosen sebagai moderator dalam perkuliahan di kelas maupun di laboratorium, dan penilaian yang diberikan selama proses diskusi. Dosen merancang bahan diskusi sesuai materi mekatronik, mahasiwa membentuk kelompok kecil untuk berdiskusi mengenai materi mekatronik, dalam mendiskusikan materi tersebut mahasiswa mencari materi secara mandiri dan dikelolah oleh anggota kelompok kecil diskusi kemudian dipresentasikan di depan kelompok yang lain. Dosen hanya menjadi moderator diskusi sekaligus menilai jalannya diskusi yang dilakukan oleh kelompok-kelompok kecil. Keaktifan masingmasing mahasiswa merupakan penilaian yang dilakukan oleh seorang dosen.

\section{METODE PENELITIAN}

Metode yang digunakan adalah eksperimen dengan jenis Quasi Eksperimental Design dengan desain penelitian Control Group Pretest-Postest Design melibatkan 2 kelas yaitu kelas ekperimen dan kontrol. Dua kelas tersebut diberikan jenis pembelajaran yang berbeda. Pada control group pretest-posttest design, baik kelompok eksprimen maupun kelompok kontrol tidak dipilih secara acak. Model desain tersebut nampak pada Tabel 1.

Dalam penelitian ini, yang menjadi populasi dalam penelitian adalah mahasiswa angkatan 2015 Teknik Mesin UMAHA. Untuk menentukan sampel penelitian menggunakan rumus Slovin, dengan taraf signifikasi 7\%. Sampel kelas 2A dan kelas 2B yang berjumlah 68 siswa.

Masing-masing kelas berjumlah 34 mahasiswa dengan ketentuan 2A kelas eksperimen (model SDL) dan kelas 2B kelas kontrol (model SGD). Data dikumpulkan melalui tiga tahap, yaitu: (1) tahap pertama, melakukan pengamatan untuk mengamati dan mendapatkan data langsung meliputi aspek sikap dan keterampilan mahasiswa selama proses kegiatan pembelajaran; (2) tahap kedua, yaitu dengan melakukan menghimpun data berupa nilai pengetahuan pada kompetensi pengetahuan Mekatronik.
Tabel 1. Control Group Pretest-Postest Design (Sugiyono, 2012)

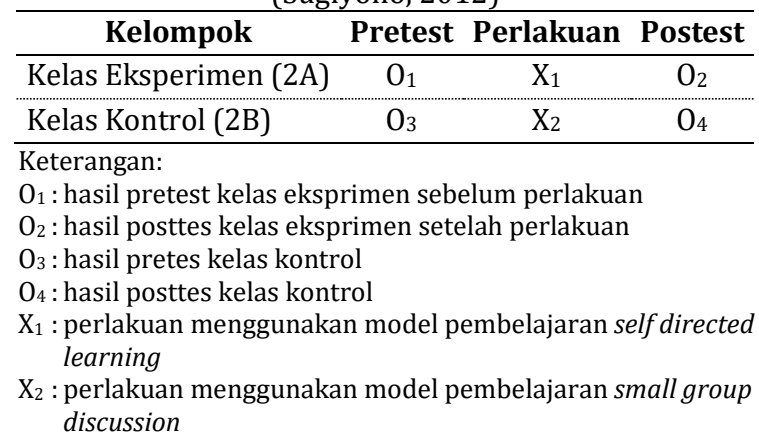

Pada penelitian ini dalam data dikumpulkan menggunakan teknik yang dilakukan melalui tiga tahap, yaitu: (1) tahap pertama, melakukan pengamatan untuk mengamati dan mendapatkan data langsung mengamati sikap dan keterampilan mahasiswa selama proses kegiatan pembelajaran; (2) tahap kedua, yaitu dengan melakukan menyiapkan dan meghimpun data berupa hasil tes untuk mengetahui nilai pengetahuan kompetensi.

\section{HASIL DAN PEMBAHASAN}

Sebelum pelaksanaan penelitian, instrumen perangkat yang telah dinyatakan valid oleh para validator yang berjumlah tiga orang yang berkompeten di bidangnya, selanjutnya dilakukan percobaan dahulu di kelas yang berbeda. Validasi meliputi instrumen lembar pengamatan nilai aspek sikap, butir soal nilai aspek pengetahuan, dan instrumen lembar pengamatan aspek keterampilan untuk mengetahui apakah perangkat tersebut sudah layak diujicobakan dari isi/materi, konstruksi, dan kebahasaan perangkat yang dibuat berdasarkan pendapat atau tanggapan para ahli.

Validitas Perangkat Pembelajaran meliputi RPS, RPP dan bahan ajar instrumen lembar pengamatan hasil belajar sikap, butir soal, nilai tes dan instrumen lembar pengamatan mahasiswa yang sedang mengadakan pembelajaran di laboratorium dari isi/materi, konstruksi, dan kebahasaan perangkat yang dibuat berdasarkan pendapat atau tanggapan para ahli. Hasil dari validasi yang mencakup RPS, RPP, bahan ajar yang dibuat dan insrumen lembar pengamatan diperoleh. Validasi ditunjukan pada Tabel 2. Hasil rekap validasi pada perangkat yang akan diujicobakan

\section{Validitas Perangkat Pembelajaran}

Validitas Perangkat Pembelajaran meliputi RPS, RPP dan bahan ajar instrumen lembar pengamatan hasil belajar sikap, butir soal, nilai tes dan instrumen lembar pengamatan mahasiswa yang sedang mengadakan pembelajaran di laboratorium dari isi/materi, konstruksi, dan 
kebahasaan perangkat yang dibuat berdasarkan pendapat atau tanggapan para ahli. Hasil dari validasi yang mencakup RPS, RPP, bahan ajar yang dibuat dan insrumen lembar pengamatan diperoleh. Validasi ditunjukan pada Tabel 2. Hasil rekap validasi pada perangkat yang akan diujicobakan.

Tabel 2. Hasil Validasi Perangkat Pembelajaran

\begin{tabular}{|c|c|c|c|}
\hline No & $\begin{array}{c}\text { Perangkat } \\
\text { Pembelajaran }\end{array}$ & Rata-rata & Kriteria \\
\hline \multicolumn{4}{|c|}{ Model Pembelajaran Self Directed Learning } \\
\hline 1 & RPS & 4,78 & Baik \\
\hline 2 & RPP & 4,36 & Baik \\
\hline 3 & Bahan ajar & 4,64 & Baik \\
\hline \multicolumn{4}{|c|}{ Model Pembelajaran Small group Discussion } \\
\hline 1 & RPS & 4,76 & Baik \\
\hline 2 & RPP & 4,36 & Baik \\
\hline 3 & Bahan ajar & 4,72 & Baik \\
\hline
\end{tabular}

\section{Validitas Instrumen}

Hasil validasi instrumen penelitian dari aspek materi, aspek kontruksi, dan aspek bahasa /penulisan butir soal diperoleh hasil seperti ditunjukkan Tabel 3.

Tabel 3. Instrumen Penelitian

\begin{tabular}{cccc}
\hline No & Jenis Instrumen & Rata-rata & Kriteria \\
\hline 1 & Lembar pengamatan nilai aspek sikap & 4,53 & Baik \\
\hline 2 & Soal nilai aspek pengetahuan & 4,27 & Baik \\
& $\begin{array}{l}\text { Lembar pengamatan nilai aspek } \\
\text { keterampilan }\end{array}$ & 4,40 & Baik \\
\hline
\end{tabular}

\section{Hasil Penelitian}

\section{Nilai Aspek Sikap Mekatronik}

Penilaian pengamatan pada kompetensi Mekatronik sebelum dilakukan analisis data dilakukan uji persyaratan diperoleh signifikasi skor nilai pengamatan sikap pada kelas eksperimen (SDL) sebesar 0,871 > 0,05 dan pada kelas kontrol (SGD) sebesar $0,718>0,05$, uji homogenitas variansi yaitu signifikasi $0,067>0,05$ pengamatan sikap diperoleh kesimpulan mahasiswa yang diterapkan model SDL dan SGD adalah homogen.

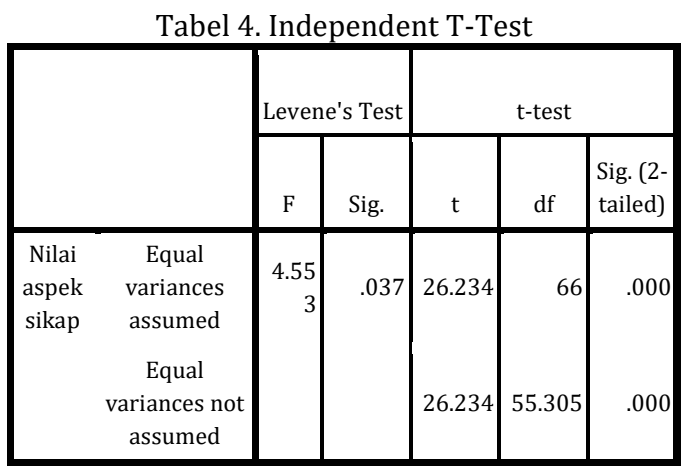

Pengujian hipotesis pada kelas yang didalammnya menggunakan model self directed learning dibandingkan dengan penilaian dalam aspek sikap mahasiswa yang didalammnya diterapkan model small group discussion digunakan Independent T-Test seperti terlihat Tabel 4.

Tabel 4 menunjukkan signifikasi $0,000<0,05$ yang berarti antara kelas yang menggunakan model pembelajaran self directed learning nilainya lebih dibandingkan dengan kelas yang menggunakan small group discussion.

\section{Nilai Aspek Pengetahuan Mekatronik}

Nilai pada aspek pengetahuan Mekatronik, dilakukan dua kali pengambilan data meliputi waktu akan mengikuti dan setelah mengikuti pembelajaran. Pengujian analisis yang dilakukan baik akan dan setelah yaitu pengujian normalitas terlebih dahulu yang hasilnya signifikasi nilai aspek pengetahuan sebesar $0,054>0,05$, uji homogenitas variansi menunjukkan signifikasi sebesar 0,099 >0,05, uji kemiringan (slope).

Hasil uji normalitas distribusi menunjukkan signifikasi nilai aspek pengetahuan (postes) mahasiswa kelas 2A dan 2B sebesar 0,675 > 0,05, uji homogenitas variansi menunjukkan signifikasi sebesar 0,645 > 0,05. Pengujian hipotesis nilai aspek pengetahuan mahasiswa pada kelas dengan model SDL dengan mahasiswa pada kelas dengan model SGD melalui proses pengujian Anakova untuk mengkontrol pengaruh pretes. Seperti tampak pada Tabel 5.

Tabel 5. Hasil Anakova

Tests of Between-Subjects Effects

Dependent Variable:Nilai

Postes

\begin{tabular}{|c|c|c|c|c|c|}
\hline Source & $\begin{array}{l}\text { Type III } \\
\text { Sum of } \\
\text { Squares }\end{array}$ & df & $\begin{array}{l}\text { Mean } \\
\text { Square }\end{array}$ & $\mathrm{F}$ & Sia. \\
\hline $\begin{array}{l}\text { Corrected } \\
\text { Model }\end{array}$ & $1066.387^{a}$ & 2 & 533.194 & 7.144 & .002 \\
\hline Intercept & 43194.003 & 1 & $\begin{array}{r}43194.00 \\
3\end{array}$ & 578.724 & .000 \\
\hline JenKls & 355.889 & 1 & 355.889 & 4.768 & .033 \\
\hline PRETES & 752.916 & 1 & 752.916 & 10.088 & .002 \\
\hline Error & 4851.378 & 65 & 74.637 & & \\
\hline Total & 430938.000 & 68 & & & \\
\hline $\begin{array}{l}\text { Corrected } \\
\text { Total }\end{array}$ & 5917.765 & 67 & & & \\
\hline
\end{tabular}

Tabel 5 Hasil Anakova menunjukkan diperoleh harga Fhitung atau F0 (kelas)= 4.768; df $(1,65)$; dengan $p$-value $=0,033<0,05$ yang berarti terdapat perbedaan rata-rata nilai aspek pengetahuan antara kelas 2A yang diterapkan model SDL dan kelas 2B dengan menerapkan model SGD setelah mengontrol pengaruh pretes. Selanjutnya dilakukan uji lanjut dengan statistik-t tampak pada Tabel 6 .

Tabel 6 menunjukkan $p$-value $=0,033<0,05$ atau $\mathrm{H}_{0}$ ditolak, dan $\mathrm{H}_{1}$ diterima. Dengan demikian terdapat perbedaan nilai aspek pengetahuan antara mahasiswa yang diterapkan SDL dengan kelas yang diterapkan SGD. 
Tabel 6. Parameter Estimates

Dependent Variable:Nilai Postes

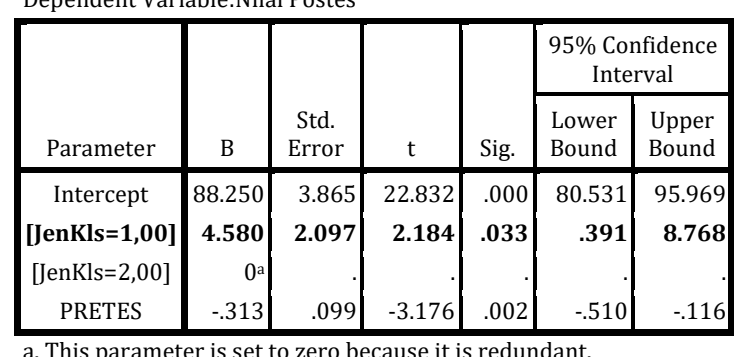

a. This parameter is set to zero because it is redundant.

\section{Nilai Pada Aspek Keterampilan Mekatronik}

Sebelum dilakukan analisis data dilakukan uji persyaratan diperoleh signifikasi skor pengamatan keterampilan kelas eksperimen (SDL) sebesar 0,494>0,05 dan pada kelas kontrol (SGD) sebesar 0,691 >0,05, uji homogenitas variansi yaitu signifikasi $0,700>0,05$ yang kesimpulannya aspek keterampilan mahasiswa kelas 2A (SDL) dan kelas 2B (SGD) menggunakan uji normalistas dengan hasil homogen.

Tabel 7 Independent T-Test

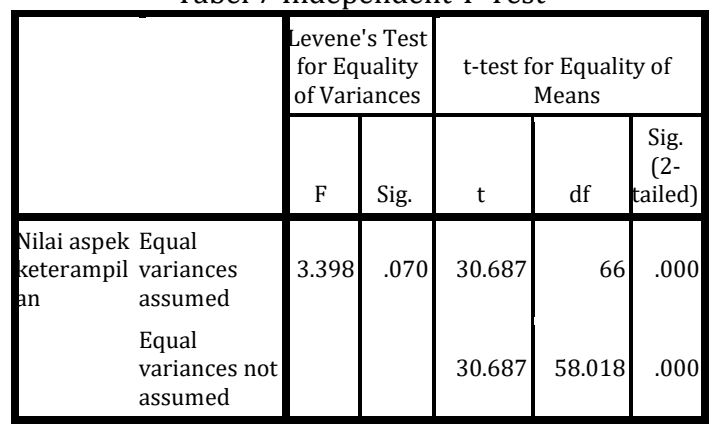

Tabel 7 menunjukkan signifikasi $0,000<$ 0,05, Ho ditolak sehingga dapat disimpulkan. Aspek keterampilan mahasiswa dengan penerapan SDL mempunyai perbedaan dengan nilai aspek keterampilan mahasiswa yang diterapkan SGD.

Aspek penilaian sikap yang berbentuk pengamatan, penilaian pengetahuan yang diberikan kepada mahasiswa berupa tes atau butirbutir pengetahuan mengenai materi mekatronika di kelas, sedangkan aspek penilaian keterampilan yang diperoleh dari pengamatan praktek mahasiswa di laboratorium saat proses pembelajaran. Hasil penilaian tersebut merupakan bukti otentik dari hasil sebuah proses pembelajaran yang diambil dan dilakukan secara terus menerus selama di kelas sebagai pedoman untuk pembelajaran selanjutnya. Penilaian yang sudah dilakukan tersebut bisa sebagai salah satu rujukan dalam pelaksanaan pembelajaran untuk mata kuliah atau materi yang lain, yang bertujuan untuk memperbaiki perencanaan, proses dan pengawasan perkuliahan di kelas yang sudah dilakukan oleh mahasiswa selama ini.
Instrumen penilaian berupa lembar pengamatan baik sikap maupun keterampilan digunakan untuk mendaftar seluruh indikator pencapaian yang sudah ditetapkan oleh prodi. Pengamatan sikap dan keterampilan tersebut dalam rangka untuk mengetahui etika dan kegiatan praktek yang dilakukan oleh mahasiswa dengan sebenar-benarnya.

Model pembelajaran yang sudah dilaksanakan baik SDL dan SGD memberikan kontribusi terhadap proses pembelajaran pada materi mekatronika yang berbeda. Pada kelas SDL lebih menitik beratkan setiap mahasiswa mampu merencanakan proses pembelajaran sendiri sedangkan SGD masih menggantungkan kepada kelompok kecil dalam inisiatif dan perencanaan dalam proses pembelajaran.

Hasil penelitian yang sudah dilakukan memperlihatkan adanya perbedaan kelas yang dilaksanakan SDL dan SGD secara signifikan. Meskipun kedua model tersebut sama-sama mengisyaratkan mahasiswa menjadi seorang yang mandiri dan mampu mencari pengetahuan secara pribadi terstruktur dan terencana. Namun tetap mempunyai kekurangan di dalam pelaksanaanya, banyak hal yang bisa mempengaruhi hal tersebut diantaranya mahasiswa yang sebelum melakukan kegiatan pembelajaran di kelas, mereka bekerja paruh waktu yaitu melakukan aktivitas yang juga membutuhkan tenaga dan daya pikir cukup tinggi.

Materi pada penelitian ini merupakan materi yang dianggap cocok untuk kedua jenis model pembelajaran yang dilakukan dalam kelas, baik teori maupun kegiatan di laboratorium. Mekatronik salah satu mata kuliah di prodi mesin UMAHA yang harus dicapai ketuntasannya oleh mahasiswa, tuntas diartikan ada tiga hal yang terpenuhi yaitu aspek pengamatan sikap, aspek nilai pengetahuan dan aspek pengamatan keterampilan yg dilaksanakan di laboratorium.

Aspek penilaian pengamatan sikap mahasiswa diperoleh dari instrumen penilaian sikap terhadap mahasiswa selama melaksanakan pembelajaran di kelas dengan cara menceklist $(\sqrt{ })$ item sikap/etika mahasiswa yang merujuk pada capaian pembelajaran mekatronik. Penilaian pengetahuan mahasiswa diperoleh dari hasil tes yang dilakukan mahasiswa tentang materi mekatronik yang disesuaikan dengan ketuntasan belajar pada mata kuliah terkait. Sedangkan aspek pengamatan keterampilan diperoleh dari pengamatan terhadap mahasiswa yang sedang melakukan kegiatan praktek di laboratorium dengan cara menceklist $(\sqrt{ })$ item pada instrumen pengamatan keterampilan yang merujuk pada kompetensi/capaian pembelajaran yang diinginkan pada materi mekatronik. 


\section{PENUTUP}

Berdasarkan analisis di atas, disimpulkan bahwa nilai pengamatan sikap, pengetahuan maupun keterampilan pada materi Mekatronik antara mahasiswa yang telah diterapkan SDL mempunyai nilai yang lebih dari pada mahasiswa yang telah diterapkan SGD.

Berdasarkan diskusi maka disarankan: (1) pembelajaran yang bersifat pengaturan sendiri, mahasiswa perlu diberikan lebih banyak melakukan persiapan terutama dalam hal membuat rencana mengenai aktivitas kegiatan belajar di kelas maupun di laboratorium, inisiatif belajar mahasiswa, dan berfikir secara mandiri, (2) pada program studi harus menyediakan perangkat lebih baik berupa bahan ajar, RPS, RPP terutama pada materi Mekatronik , (3) pada kelas 2A dan 2B pada Prodi Mesin lebih cocok menggunakan SDL daripada SGD, (4) mahasiswa diberikan motivasi untuk bertanya pada proses belajar menggunakan istilah-istilah penting yang belum diketahui dan memberikan nilai bagi mahasiswa yang mengajukan pertanyaan.

\section{DAFTAR PUSTAKA}

Anam, K., \& Choifin, M. (2017). Implementasi Model Four-d (4d) untuk Pembelajaran Aplikasi Multiplatform Penggolongan Hewan Berdasarkan Makanannya. Teknika: Engineering and Sains Journal, 1(2), 111116.

Azwar; S. (1997). Reliabilitas dan validitas. Yogyakarta: Pustaka Pelajar.

Gibbons; M. (2003). The self-directed learning handbook: Challenging adolescent students to excel. John Wiley \& Sons.

Gunawan, E. (2017). Analisa Pengaruh Temperatur Terhadap Sifat Mekanis Dan Struktur Mikro Pada Baja Karbon Rendah (St41) Dengan Metode Pack Carbirizing. Teknika: Engineering and Sains Journal, 1(2), 117124.

Gunawan, E. (2017). Pengaruh Temperatur pada Proses Perlakuan Panas Baja Tahan Karat Martensitik AISI 431 terhadap Laju Korosi dan Struktur Mikro. Teknika: Engineering and Sains Journal, 1(1), 55-66.

Hariyanto; I. B. D. (2014). Asesmen Pembelajaran. Bandung: PT. Remaja Rosdakarya.
Hosnan; M. (2014). Pendekatan saintifik dan kontekstual dalam pembelajaran abad 21: Kunci sukses implementasi kurikulum 2013. Ghalia Indonesia.

Huda; M. (2013). Model-model pengajaran dan pembelajaran. Yogyakarta: pustaka pelajar.

Kelly; M.; \& Stafford; K. (1993). Managing small group discussion. Professional Development Unit; City Polytechnic of Hong Kong.

Naga; D. S. (1992). Pengantar teori sekor pada pengukuran pendidikan. Jakarta: Gunadarma.

Pallant; J. (2013). SPSS survival manual. McGrawHill Education (UK).

Perdana, D. (2017). Pengaruh Variasi Temperatur pada Proses Perlakuan Panas Baja AISI 304 Terhadap Laju Korosi. Teknika: Engineering and Sains Journal, 1(1), 67-72.

Prasnowo, M. A., Khomaruddin, A., \& Hidayat, K. (2017). Strategi Pengembangan Sentra Industri Kecil Menengah Produksi Krupuk. Teknika: Engineering and Sains Journal, 1(1), 17-24

Pulley; P. A. (2004). Developing an instructional model in an industrial application. Online Journal for Workforce Education and Development; 1(1); 2.

Purwanto. (2009). Evaluasi Hasil Belajar. Pustaka Pelajar.

Scott; K. W. (2006). Self-directed learners' concept of self as learner: Congruous autonomy. International Journal of Self-Directed Learning; 3(2); 1-13.

Sudjana; N. (2005). Metode statistika. Bandung: Tarsito; 168.

Sukarjadi, S., Arifiyanto, A., Setiawan, D. T., \& Hatta, M. (2017). Perancangan dan Pembuatan Smart Trash Bin di Universitas Maarif Hasyim Latif. Teknika: Engineering and Sains Journal, 1(2), 101-110.

Supardi; U. S. (2013). Aplikasi statistika dalam penelitian. Jakarta: Change Publisher.

Viera; A. J.; \& Garrett; J. M. (2005). Understanding interobserver agreement: the kappa statistic. Fam Med; 37(5); 360-363.

Wiraghani, S. R., \& Prasnowo, M. A. (2017). Perancangan dan Pengembangan Produk Alat Potong Sol Sandal. Teknika: Engineering and Sains Journal, 1(1), 73-76. 
W Lestariningsih, dkk / Teknika : Engineering and Sains Journal, Vol. 2, No.1, Juni 2018, 67-72

Halaman ini sengaja dikosongkan 